\title{
Bloom and decline of the toxic flagellate Chattonella marina in a Swedish fjord
}

\author{
Anya M. Waite ${ }^{1, *}$, Odd Lindahl ${ }^{2}$ \\ ${ }^{1}$ School of Environmental Systems Engineering, University of Western Australia, 35 Stirling Highway, Crawley 6009, \\ Western Australia, Australia \\ ${ }^{2}$ Royal Swedish Academy of Sciences, Kristineberg Marine Research Station, PO Box 566, 45034 Fiskebäckskil, Sweden
}

\begin{abstract}
During March 2001, after a spring diatom bloom, the toxic flagellate Chattonella marina bloomed in surface waters of the Gullmar fjord, Sweden, to cell concentrations of 1 to $2 \times 10^{3} \mathrm{ml}^{-1}$, with a strong subsurface maximum ( 2 to $5 \mathrm{~m}$ ). While the diatoms' isotopic composition indicated a preference for nitrate as an $\mathrm{N}$ source, the flagellate seemed to utilize a higher fraction of recycled nutrients (ammonium) when nitrate was severely depleted by the diatoms, allowing it to remain in surface waters once the diatoms sank from the surface. C. marina had production rates of $\sim 20 \mathrm{mg} C$ $\mathrm{m}^{-3} \mathrm{~h}^{-1}$ and turnover rates of 2 to $5 \mathrm{~d}^{-1}$. The size distribution shifted from larger to smaller cells by the end of the bloom, and the total carbon that $C$. marina contributed to the system was about $1000 \mathrm{mg} C$ $\mathrm{m}^{-2}$. Concurrently, heterotrophic dinoflagellates (especially Peridinella danica) grew to a total biomass of $1500 \mathrm{mg} \mathrm{C} \mathrm{m}^{-2}$, and had a net growth rate of $0.06 \mathrm{~d}^{-1}$. Our results suggest that heterotrophic dinoflagellates had the capacity to be primary grazers of $C$. marina, and could have easily accounted for the decline of the $C$. marina bloom in surface waters. Both $C$. marina and the heterotrophic dinoflagellates made a measurable but small $\left(20\right.$ to $40 \mathrm{mg} \mathrm{C} \mathrm{m}^{-2}$ ) contribution to sedimented carbon.
\end{abstract}

KEY WORDS: Algal bloom · Chattonella marina $\cdot$ Peridiniella danica $\cdot$ Heterotrophic dinoflagellates · Grazing $\cdot$ Nutrients

Resale or republication not permitted without written consent of the publisher

\section{INTRODUCTION}

In recent years, there have been a number of documented blooms of the toxic Raphidophyte Chattonella spp. in coastal waters (Vrieling et al. 1995, Kohata 1997, Tiffany et al. 2001), including those involving large fish mortalities (Bourdelais et al. 2002), which possibly resulted from the generation of brevetoxins (Bourdelais et al. 2002) or superoxide anions (Tanaka et al. 1992). Such reports have compounded concerns regarding the possible harmful effects of anthropogenic changes in coastal water quality (Alanji et al. 2001), and highlight the need for further knowledge on the ecology and dynamics of this particular genus for the purpose of effective coastal management. However, Chattonella spp. blooms have in fact been associated with low, rather than high, nutrient concentrations. Ono et al. (1999) suggested that when diatoms strip nutrients from surface waters, the capacity of Chattonella spp. to take up nutrients at very low nutrient concentrations may favour this species' successional post-spring bloom. This would mean that stratification, not eutrophication, is a proximal bloom trigger for Chattonella spp. blooms.

Here we document the bloom and grazing-mediated decline of Chattonella marina in a coastal Swedish fjord, the Gullmar Fjord, during a period when the species formed a massive bloom over hundreds of square kilometers covering the entire northeast Skagerrak, from southern Sweden up the Swedish west coast to Norway (Naustvoll et al. 2002). This was the third such bloom in the region, the first 2 being documented in 1991 and 1998. We utilize cell isotopic composition to determine the likely nutrient source utilized by this flagellate, and speculate as to the likely causes of bloom decline. 


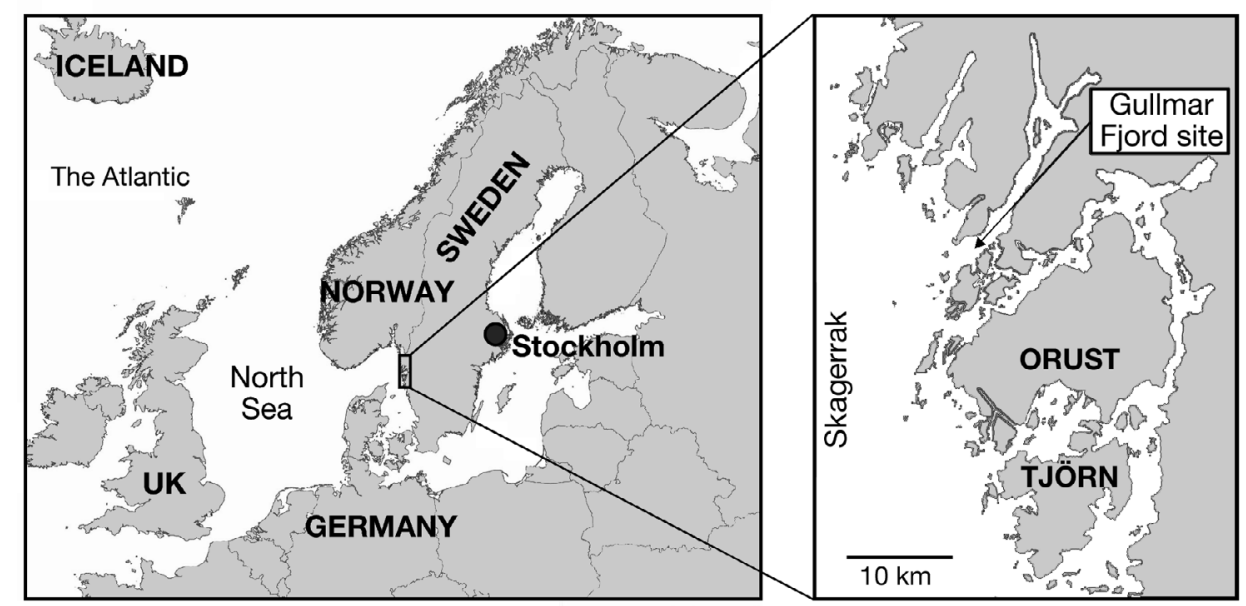

Fig. 1. Location of the Gullmar Fjord study site, Sweden

\section{MATERIALS AND METHODS}

Between March 13 and April 4, 2001, we sampled the water column down to $50 \mathrm{~m}$ depth 3 times per week at a station in the central Gullmar Fjord, Sweden (Fig. 1), maximum fjord depth $120 \mathrm{~m}$. All field operations were based at the Kristineberg Marine Research Station (KMRS) near Fiskebäckskil. Sampling was undertaken from KMRS's RV 'Arne Tiselius', and consisted of CTD casts and Niskin bottle sampling at 8 to 10 depths from 0 to $50 \mathrm{~m}$, with most detailed sampling in the mixed layer. Subsamples from each depth were filtered on GF/F filters for chl $a$ and particulate organic matter (POC/PON and isotopic composition analysis, see below), and filtrate $(25 \mathrm{ml})$ was retained for nutrient analysis. Cell count samples were taken from the chlorophyll maximum (2 to $5 \mathrm{~m}$ ) as indicated by the fluorescence trace. A sampling hose was also lowered to $15 \mathrm{~m}$ to yield integrated mixed layer samples for cell count analysis. Two vertical net hauls from $15 \mathrm{~m}$ to the surface were also executed using a $>90 \mu \mathrm{m}$ plankton net to isolate the population of large diatoms for POC/ PON and isotopic composition analysis. All phytoplankton and ciliates were preserved with acetic Lugol solution, and cells larger than $10 \mu \mathrm{m}$ were counted by the Utermöhl technique (Utermöhl 1958) using a Leitz DMRIB microscope.

Chl a samples were ground and extracted in $10 \mathrm{ml}$ acetone and analysed immediately for chl a concentration on a Turner Designs AU-10 fluorometer (Parsons et al. 1984). Particulate carbon samples were first mildly acidified in Ag capsules and then analyzed for POC, PON, $\delta^{13} \mathrm{C}$ and $\delta^{15} \mathrm{~N}$ as follows: stable isotope abundances and ratios of carbon and nitrogen were measured by continuous flow isotope ratio mass spectrometry (20-20 mass spectrometer, PDZEuropa) after sample combustion to $\mathrm{CO}_{2}$ and $\mathrm{N}_{2}$ at $1000^{\circ} \mathrm{C}$ in an on-line elemental analyzer
(PDZEuropa ANCA-GSL). The gases were separated on a Carbosieve G column (Supelco) before introduction to the isotope ratio mass spectrometer (IRMS). Sample isotope ratios were compared to those of standard gases injected directly into the IRMS before and after the sample peaks, and $\delta^{15} \mathrm{~N}$ (vs. air) and $\delta^{13} \mathrm{C}$ (vs. PDB) values were subsequently calculated.

Net primary production was measured using ${ }^{14} \mathrm{C}$ uptake each sampling day at a separate long-term station near the fjord sill, according to the protocol developed by Lindahl (1995). Samples from 9 depths were incubated in situ for $4 \mathrm{~h}$ on a mooring adjacent to KMRS, and measured production was integrated over depth and time. Cell counts were converted to cell carbon based on cell carbon estimates of Edler (1977) and cell size estimates for Peridiniella danica from M. Kulenstierna (pers. comm.). Sediment traps (8 $\mathrm{cm}$ diameter and $55 \mathrm{~cm}$ height) were deployed at 15 and $30 \mathrm{~m}$ depths in the centre of the fjord and collected, emptied, and redeployed every 2 to 3 d between March 14 and April 4 . Samples were preserved in Lugol's solution for cell counts of the trap material. Cell counts of Chattonella marina and heterotrophic dinoflagellates were converted to cell carbon as above. Species-specific estimates of carbon uptake and turnover rates $(\mathrm{T})$ were calculated from measured ${ }^{14} \mathrm{C}$ uptake and POC values in surface waters on March 16 and March 23 (when C. marina contributed $\sim 82$ to $97 \%$ of total phytoplankton POC; Waite et al. 2005) as follows: $\mathrm{T}\left(\mathrm{d}^{-1}\right)=$ carbon uptake $(\mathrm{mg}$ $\mathrm{C} \mathrm{m}^{-3} \mathrm{~d}^{-1}$ )/carbon concentration $\left(\mathrm{mg} \mathrm{C} \mathrm{m}^{-3}\right)$.

\section{RESULTS}

Primary production in the Gullmar fjord in March 2001 peaked at the subsurface fluorescence maximum (3 m) with a value of $34.8 \mathrm{mg} \mathrm{C} \mathrm{m}^{-3} \mathrm{~h}^{-1}$ on March 16 


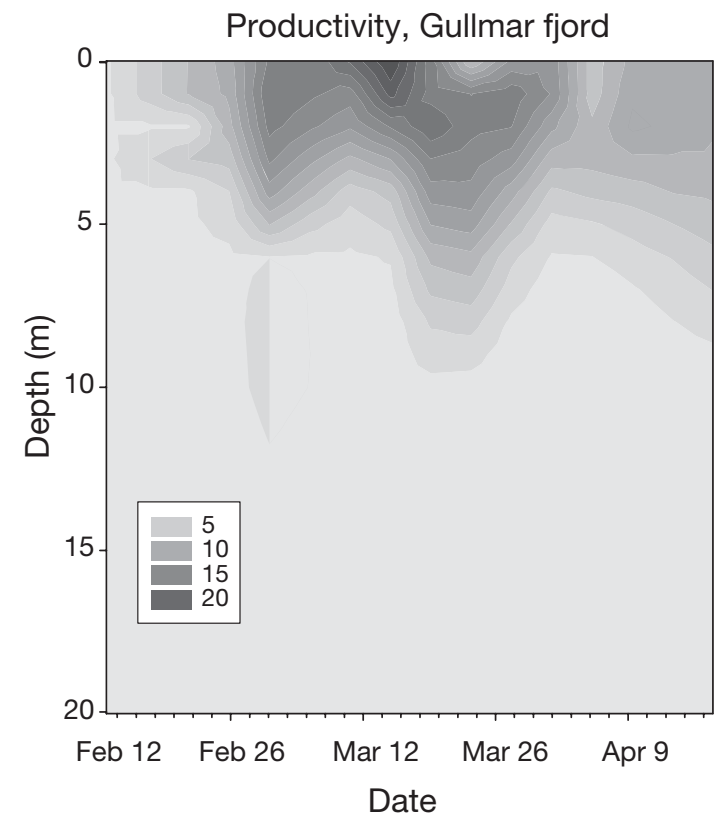

Fig. 2. Primary production (mg $\left.\mathrm{C} \mathrm{m}^{-3} \mathrm{~h}^{-1}\right)$ with depth and time. Subsurface peaks on March 16 and 20-22 correspond to high concentrations of Chattonella marina ( 82 to $97 \%$ of phytoplankton carbon by weight)
(Fig. 2). This peak was associated with a large population of Chattonella marina cells, which were identified in the surface chlorophyll peak in the Gullmar fjord on the first sampling day (March 14). This flagellate bloom occurred against the backdrop of what appeared to be a declining population of diatoms, including Skeletonema costatum $\left(\sim 125\right.$ cells $\left.\mathrm{ml}^{-1}\right)$ and Chaetoceros spp. $\left(\sim 200\right.$ cells $\left.\mathrm{ml}^{-1}\right)$, as well as smaller numbers $\left(<10\right.$ to 70 cells $\left.\mathrm{ml}^{-1}\right)$ of Thalassiosira sp., Guinardia sp., Coscinodiscus sp., and various pennate diatoms, all of which declined steeply to trace numbers by March 23 (Fig. 3). This suggested the presence of a spring diatom bloom in surface waters in the preceding days or weeks (Fig. 3), which contributed significantly to sediment trap fluxes (data not shown) and depleted nutrients deep in the water column (Fig 3). Depthintegrated cell numbers of $C$. marina multiplied rapidly to a peak of $\sim 1000$ cells $\mathrm{ml}^{-1}$ on March 16 (Fig. 3). Turnover times of carbon, calculated when $C$. marina contributed 82 to $97 \%$ to total POC, ranged from 1.9 to $4.9 \mathrm{~d}^{-1}$. A biomass drop on March 19 coincided with a documented upwelling event which dominated the surface waters of the fjord and displaced surface waters, increasing surface nitrate significantly

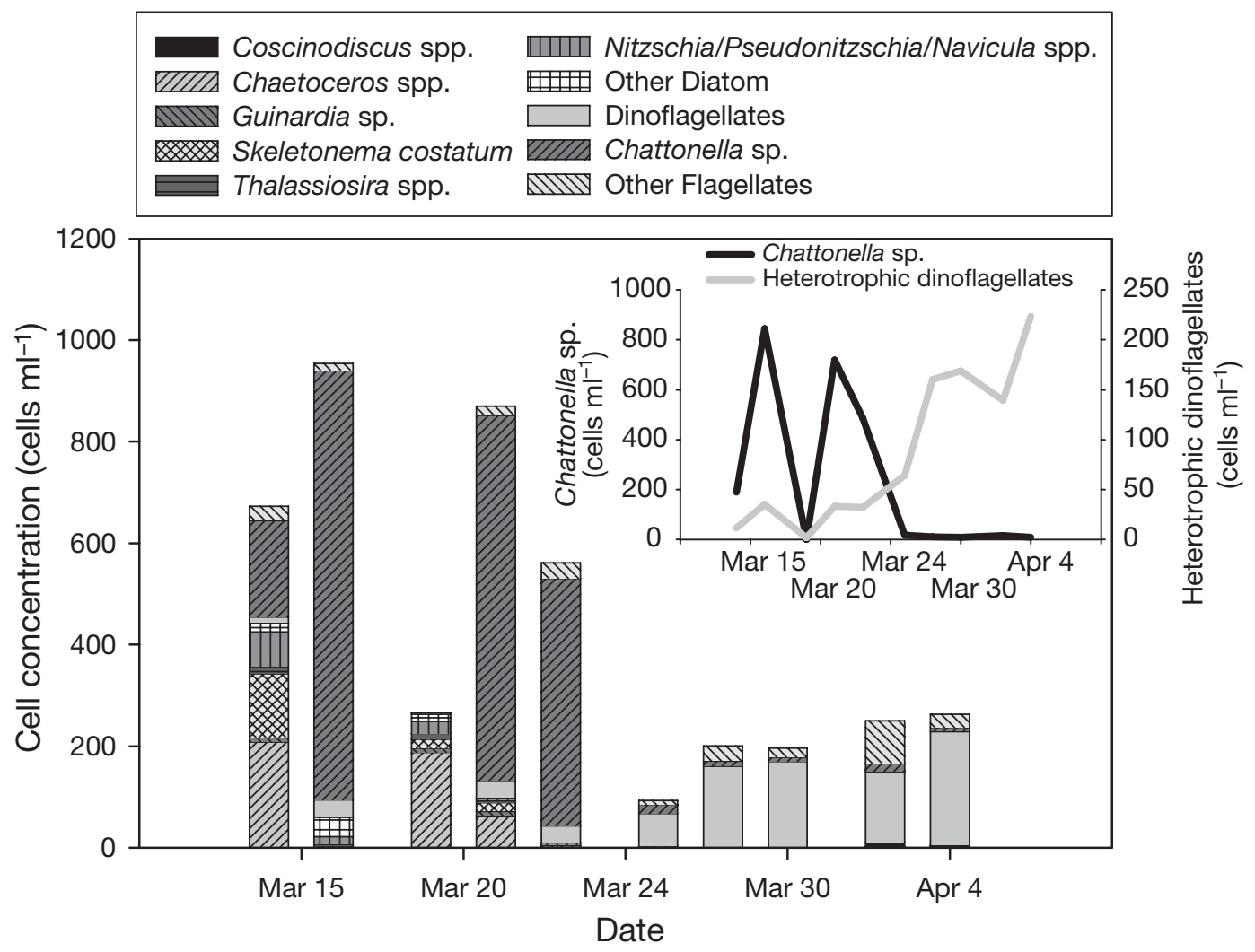

Fig. 3. Cell concentrations of diatoms, Chattonella marina and heterotrophic dinoflagellates dominated (>75\% C) by Peridiniella danica, vs. time. All samples collected as integrated hose samples over top $15 \mathrm{~m}$ of water column. Drop in cell numbers on March 19 corresponds to a short-term upwelling event that relaxed the following week. Insert: C. marina and heterotrophic dinoflagellate concentrations vs. time, showing relative abundances (note separate axes) 


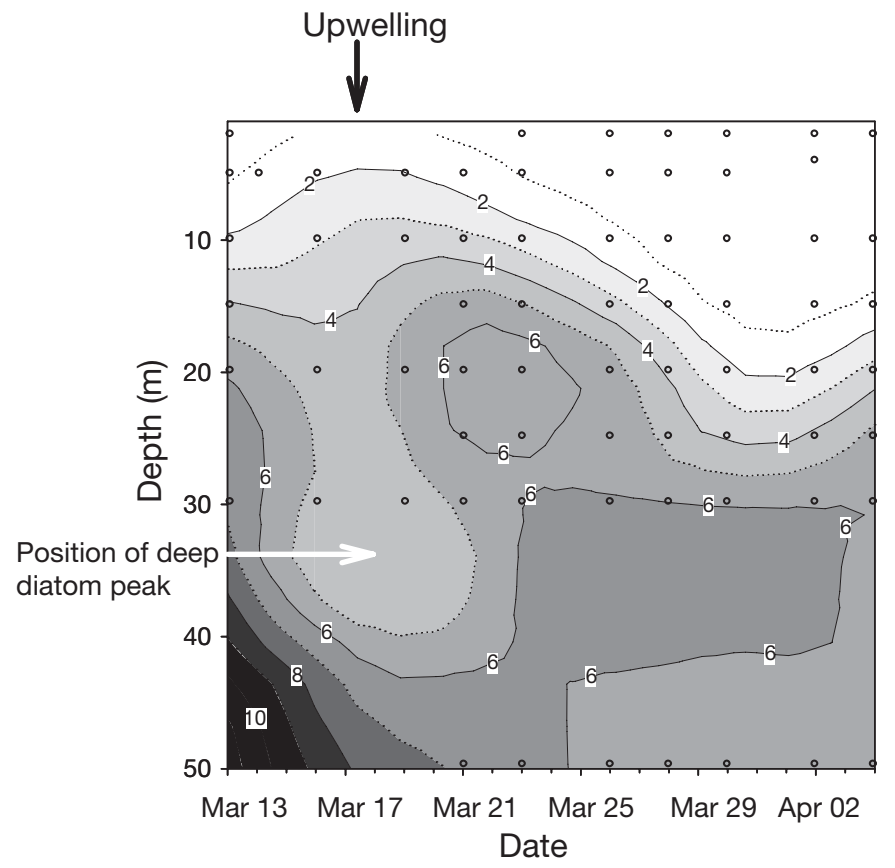

Fig. 4. Nitrate concentrations $\left(\mu \mathrm{mol} \mathrm{l}^{-1}\right)$ with depth and time (modified from Waite et al. 2005). o: sampling depths and times. Note depletion to undetectable values of nitrate down to $\sim 20 \mathrm{~m}$ depth by March 30. Upwelling and diatom peak are labelled

(Fig. 4; Waite et al. 2005). Relaxation of the upwelling brought C. marina cells back into the fjord (Fig. 3), with subsequent drawdown of nitrate to undetectable trace levels at the surface, and a significant deepening of the nitricline as the study progressed (Fig. 4). Ammonium levels were highly variable with no significant depth trend, and did not drop below $0.3 \mu \mathrm{mol} \mathrm{l}^{-1}$ (data not shown).

Isotopic composition of particulate matter indicated that the net hauls that contained almost pure diatom biomass (as determined microscopically), dominated mostly by Coscinodiscus spp., had a heavy carbon composition $\left(\delta^{13} \mathrm{C} \sim 18 \%\right.$ ) and high $\delta^{15} \mathrm{~N}(\sim 8 \%$; Fig. 5). In contrast, bottle casts taken when Chattonella marina represented $>82 \%$ of the biomass showed a statistically lighter $\delta^{13} \mathrm{C}$ and lower $\delta^{15} \mathrm{~N}$ composition ( $t$-test, $\mathrm{p}<0.0002$; Fig. 5), making these 2 co-existing populations very distinct from each other in isotopic composition. The C. marina $\mathrm{C}$ and $\mathrm{N}$ isotopic composition was more typical of the particulate organic matter as a whole (Fig. 5).

Chattonella marina cells often formed a strong subsurface abundance peak at $\sim 2$ to $5 \mathrm{~m}$ (corresponding to the fluorescence maximum), which was several times greater than the integrated mean cell concentrations between 0 and $15 \mathrm{~m}$ as sampled by hose. This was especially obvious on March 19, when the subsurface peak was >60 times more concentrated than mean integrated cell numbers from 0 to $15 \mathrm{~m}$.

Chattonella marina cells became $~ 50 \%$ smaller during the bloom ( $t$-test, $\mathrm{p}<0.0001, \mathrm{n}=50$ ), changing from a mean length of $34.6 \mu \mathrm{m}$ and cell carbon content of $85 \mathrm{pg} \mathrm{C} \mathrm{cell}^{-1}\left(\sim 800 \mathrm{\mu m}^{3}\right)$ to a mean length of $19.8 \mu \mathrm{m}$ and carbon content of $48 \mathrm{pg} \mathrm{C} \operatorname{cell}^{-1}\left(\sim 400 \mu \mathrm{m}^{3}\right)$; however, cell volumes ranged widely, from $<200 \mu^{3}$ to $1600 \mu^{3}$ (Fig. 6). The maximum integrated carbon (0 to $15 \mathrm{~m}$ ) contributed by C. marina sp. was $1140 \mathrm{mg}$ $\mathrm{C} \mathrm{m} \mathrm{m}^{-2}$.

Concurrently, heterotrophic dinoflagellates grew to a maximum integrated biomass of $1530 \mathrm{mg} \mathrm{C} \mathrm{m}^{-2}$. This large population of heterotrophic dinoflagellates dominated the declining phase of the Chattonella marina bloom, increasing rapidly from background concentra-

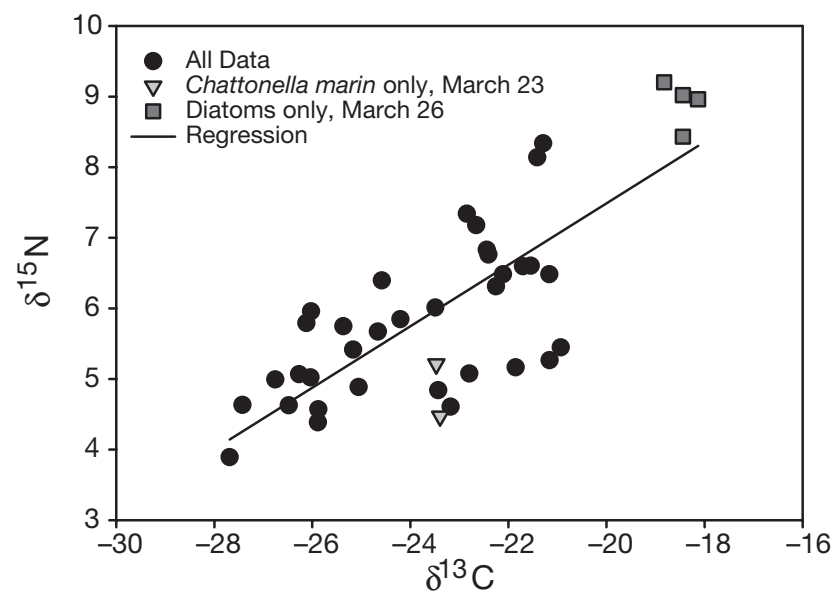

Fig. 5. Isotopic composition $\left(\delta^{15} \mathrm{~N}\right.$ and $\left.\delta^{13} \mathrm{C} \%\right)$ of particulate organic matter. Samples collected at the same depth and times as shown in Fig. 4. Note distinctive isotopic compositions of diatoms from $>90 \mu \mathrm{m}$ net haul (squares) and bottle samples containing $>85 \%$ Chattonella marina biomass (triangles), respectively

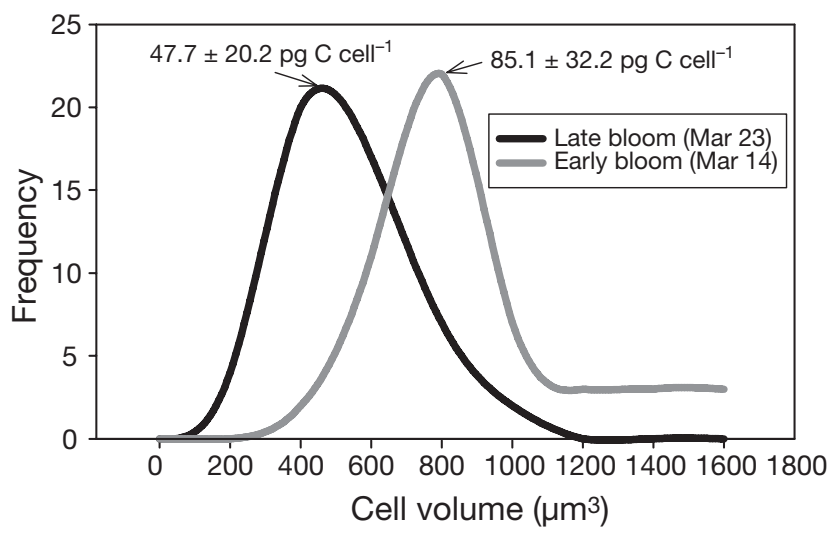

Fig. 6. Chattonella marina. Cell size distribution on March 14 (early bloom) and March 23 (late bloom). Mean cell carbon estimates $( \pm \mathrm{SD})$ for early and late blooms are given 


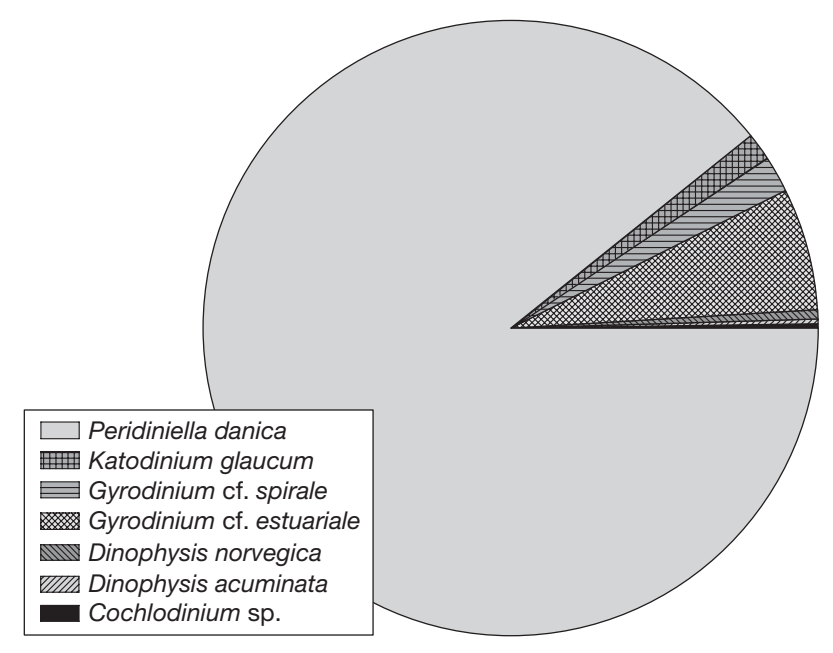

Fig. 7. Dinoflagellate species composition at peak of heterotrophic dinoflagellate biomass, as \% total dinoflagellate carbon. Note dominance of Peridiniella danica; Heterocapsa triquetra present at $<0.1 \%$ (not visible on chart)

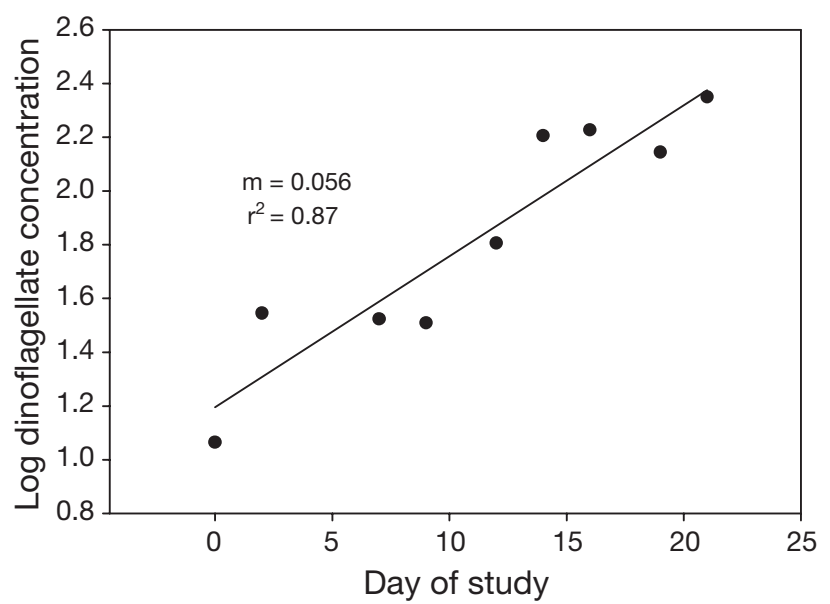

Fig. 8. Plot of log dinoflagellate abundance vs. time. Slope (m) of relationship gives estimated net growth rate $(\mu) \sim 0.06 \mathrm{~d}^{-1}$

tions on March 14 to $\sim 250$ cells $\mathrm{ml}^{-1}$ on April 4. The dinoflagellate biomass was dominated by the heterotroph Peridiniella danica, which contributed $>75 \%$ of dinoflagellate carbon (Fig. 7). Other important species were Cochlodinium sp., Gyrodinium cf. estuariale and G. cf. spirale, Dinophysis norvegica and Katodinium glaucum (Fig. 7). Dinoflagellate biomass increased exponentially, with a net growth rate $(\mu)$ of $0.06 \mathrm{~d}^{-1}$ (Fig. 8). Between March 20 and 25, as numbers and biomass of heterotrophic dinoflagellates increased, C. marina concentrations underwent a massive decline to almost undetectable numbers in surface waters (Fig. 3). Sediment trap data indicated that only $13 \mathrm{mg} \mathrm{C} \mathrm{m}^{-2}$ of C. marina was collected in the $30 \mathrm{~m}$ sediment trap in the fjord over the period of the study $(20 \mathrm{~d})$, whereas $37.5 \mathrm{mg}$ $\mathrm{C} \mathrm{m} \mathrm{m}^{-2}$ of dinoflagellate biomass was collected in the

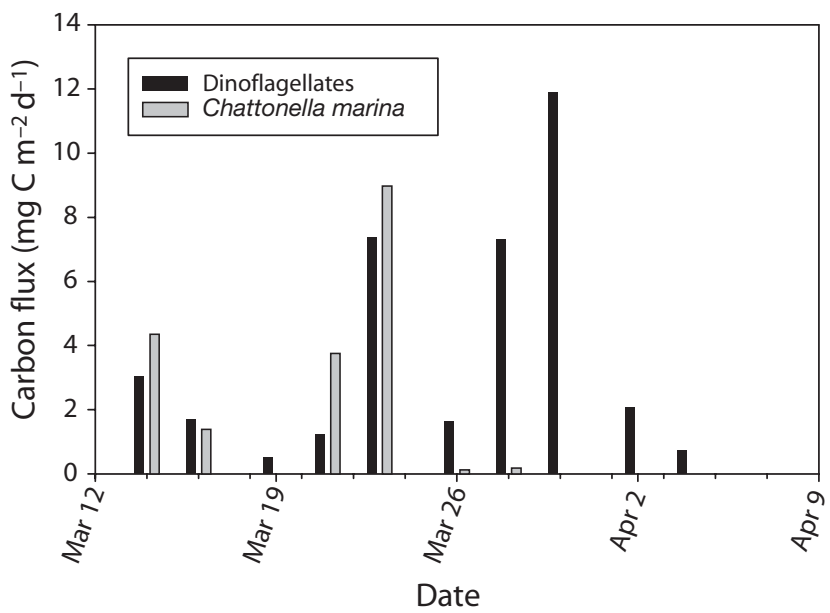

Fig. 9. Chattonella marina and heterotrophic dinoflagellates. Flux of carbon to sediment traps; peak flux occurred roughly 3 to $6 \mathrm{~d}$ after peak biomass in surface waters. Losses were not a significant fraction of water column biomass. Dates are in 2001

sediment traps over the same period. Biomass flux of C. marina peaked on March 23, while dinoflagellate biomass flux peaked on March 30 (Fig. 9).

\section{DISCUSSION}

The growth and decline of the bloom of the toxic flagellate Chattonella marina dominated surface waters in the Gullmar Fjord, Sweden, over the period of our study. Both processes seemed to be driven by interactions occurring almost exclusively in the top $5 \mathrm{~m}$ of the fjord, with sedimentation unimportant as a loss term. C. marina biomass was the single largest contributor to phytoplankton carbon in surface waters during the study period, and its biomass peaks coincided with primary production peaks. Unlike the diatoms, which were observed to depths of $30 \mathrm{~m}$ in the water column, subsurface peaks of $C$. marina (identified by the fluorescence maxima) were found (diurnally) only to $\sim 5 \mathrm{~m}$.

Diel migration by cells, undertaken in order to access deep nutrients, can only occur when nutriclines are shallow enough for cells to reach them ( $6 \mathrm{~m}$, Amano et al. 1998). In the present study, the nutricline deepened from $3 \mathrm{~m}$ to below $10 \mathrm{~m}$ between March 20 and 26 , the period of bloom decline. It is probable that during this time the nutricline became too deep for cells' diel migration to access high concentrations of nutrients, thus limiting growth rates via nutrient limitation. Unless diel vertical migration could carry populations downward to access nutrients below the nutricline, Chattonella marina would have been restricted to the area of the water column in which nitrate concentrations became strongly limiting as the study progressed. 
Other studies have found that when Chattonella sp. is isolated in surface waters depleted of inorganic nutrients after a diatom bloom, cells can exhibit extremely efficient usage of low inorganic nutrient concentrations, in combination with utilization of organic sources of nitrogen and phosphorus. In our study, ammonium concentrations did not drop below $0.3 \mu \mathrm{mol} \mathrm{l}^{-1}$ and would have probably provided a significant resource for a flagellate species, especially when considering the inferred high grazing rates (see below) and high turnover of biomass (up to $5 \mathrm{~d}^{-1}$ ) that suggested high nutrient turnover. The significantly lower $\delta^{15} \mathrm{~N}$ composition of Chattonella sp. further supports the notion that this group depends on a more recycled nutrient source (ammonium) than diatoms, whose $\delta^{15} \mathrm{~N}$ composition at $\sim 8 \%$ was as high as, or higher than, a typical oceanic nitrate signature $(\sim 5 \%$; Montoya et al. 2002). In fact, this higher $\delta^{15} \mathrm{~N}$ composition suggests that chemical transformations such as denitrification may be important in the fjord; such processes have been known to substantially increase the $\delta^{15} \mathrm{~N}$ of deep dissolved nitrate, especially in deep waters where dissolved oxygen concentrations are low (Brandes et al. 1998, Voss et al. 2001).

Finally, the difference between the $\delta^{15} \mathrm{~N}$ of these important ecosystem components, in combination with their documented differences in sinking tendencies (Waite et al. 2005), indicates that nitrogen as well as carbon is likely to undergo sinking fractionation in this ecosystem, meaning that organic matter with high $\delta^{15} \mathrm{~N}$ signatures is significantly more likely to reach the sediments.

The small amount of Chattonella marina carbon in the sediment traps, in comparison to the total maximum integrated biomass, suggests that sedimentation and/or downward migration were not major loss terms for this species. Losses that did occur peaked roughly 3 to $6 \mathrm{~d}$ after the bloom peak. Given that heterotrophic dinoflagellates are known to graze on Chattonella spp. (Nakamura et al. 1992), the large, exponentially increasing population of heterotrophic dinoflagellates (dominated by Peridiniella danica) is one likely cause of the bloom decline. Some dinoflagellates will shift to mixotrophy at low growth rates (Litaker et al. 2002), and specific growth rates of heterotrophic dinoflagellates have been documented up to $1.63 \mathrm{~d}^{-1}$ (Jeong et al. 2005), with a distinct preference for flagellates over diatoms (Legrand et al. 1998). Other studies have shown heterotrophic dinoflagellates to be the primary grazers of C. marina, and have calculated assimilation efficiencies of $\sim 0.31$ to 0.33 (Nakamura et al. 1992). Such efficiencies would indicate that, in order to reach a biomass of $1500 \mathrm{mg} \mathrm{m}^{-2}$, dinoflagellates must consume as much as $\sim 4500 \mathrm{mg} \mathrm{C} \mathrm{m}^{-2}$ over $20 \mathrm{~d}(\sim 225 \mathrm{mg}$ $\mathrm{C} \mathrm{m} \mathrm{m}^{-2} \mathrm{~d}^{-1}$ ). This easily matches the maximum water column primary production rates, attributable largely to C. marina, measured over the period March 14 through $25\left(\sim 4100 \mathrm{mg} \mathrm{C} \mathrm{m}{ }^{-2}\right.$, integrated from 0 to $20 \mathrm{~m})$. It therefore seems highly likely that dinoflagellate heterotrophs were the primary cause of the decline in $C$. marina numbers.

Interestingly, these same heterotrophs contributed more biomass to the sediment traps by a factor of 3 , suggesting that dinoflagellates that graze on Chattonella marina carbon eventually contributed more to vertical loss from sedimentation and/or downward migration than C. marina itself. Although macrozooplankton were not abundant in the fjord, they would have represented another potential loss term for the dinoflagellates; however, low concentrations during the time of our study (Waite et al. 2005) suggested that grazing was not a serious limiting factor for the dinoflagellate population during this period. Low copepod grazing rates have, for example, been shown to be of key importance in allowing dinoflagellate populations to achieve exponential growth rates in the field (Litaker et al. 2002). The dinoflagellate population was still robust when our study was completed on April 4, such that the eventual fate of this population is unknown.

The shift in size distribution from larger to smaller cells by the end of the Chattonella marina bloom is interesting, and indicates a possible shift driven by high grazing rates and/or low nutrient concentrations on the largest cells. Heterotrophic dinoflagellates have a highly specific preferred predator-to-prey size ratio ranging from 0.7:1 to 3.5:1 (Naustvoll 2000). We speculate that this halving in mean cell size of $C$. marina might have occurred due to intensive targeting of a specific range of cell sizes by the dinoflagellates. The resulting smaller-sized prey population might have then actually sustained lower mean grazing rates if cells fell below the preferred size range. The lack of specific measurements of the size of Peridiniella danica in this study preclude a detailed analysis; however, anecdotal observations indicate that this species generally occurs between 15 and $20 \mu \mathrm{m}$ in length in the Skagerrak (M. Kuylenstierna pers. comm.), suggesting that in this case the dinoflagellate predator was generally smaller than the flagellate prey. Therefore, the volume ratio for the larger cells could easily have changed from $\sim 0.5: 1$ to $1: 1$ as $C$. marina decreased in size. This would certainly not decrease availability to $P$. danica according to the range of theoretically preferred predator:prey ratios as determined by Naustvoll (2000). Alternatively, the change in cell size may simply be a reflection of the physiological growth response to a progressive reduction in the (already low) inorganic nutrient concentrations, with a higher surface area:volume ratio favouring more rapid growth of smaller cells with higher uptake ratios. 


\section{CONCLUSIONS}

We show here that after the decline of a spring diatom bloom, a dense bloom of the harmful flagellate alga Chattonella marina occurred in a coastal fjord, with extremely high carbon fixation rates. Isotopic composition suggested that this flagellate utilized significant amounts of recycled nitrogen, while the diatoms preferentially incorporated nitrate. Turnover rates of carbon in waters where $C$. marina dominated the biomass (82 to $97 \%$ ) were up to $5 \mathrm{~d}^{-1}$. The high turnover may have been due to grazing by abundant heterotrophic dinoflagellates (mainly Peridiniella danica), which increased in abundance as C. marina declined, and would have had the capacity to control C. marina biomass even at moderate grazing rates.

Acknowledgements. We thank B. Alexander, K. McMahon and E. Selander for technical support in the field, and colleagues O. Gustafsson and P. Tiselius for their valuable contributions. This project was supported by an Australian Research Council Large Grant to A.M.W.

\section{LITERATURE CITED}

Ajani P, Hallegraeff G, Pritchard T (2001) Historic overview of algal blooms in marine and estuarine waters off New South Wales, Australia. Proc Linn Soc New South Wales 123:1-22

Amano K, Watanabe M, Kohata K, Harada S (1998) Conditions necessary for Chattonella antiqua red tide outbreaks Limnol Oceanogr 43:117-128

Bourdelais AJ, Tomas CR, Naar J, Kubanek J, Baden DG (2002) New fish-killing alga in coastal Delaware produces neurotoxins. Environ Health Perspect 110:465-470

Brandes JA, Devol AH, Yochinari T, Jayakumar DA, Naqvi SWA (1998) Isotopic composition of nitrate in the central Arabian Sea and eastern tropical North Pacific: a tracer for mixing and nitrogen cycles. Limnol Oceanogr 43: 1680-1689

Edler L (1977) Phytoplankton and primary production in the Sound. PhD thesis, Gothenburg University

Jeong HJ, Kim JS, Kim JH, Kim ST, Seong KA, Kim TH, Song JY, Kim SK (2005) Feeding and grazing impact of the newly described heterotrophic dinoflagellate Stoeckeria algicida on the harmful alga Heterosigma akashiwo. Mar Ecol Prog Ser 295:69-78

Kohata K, Watanabe M, Yamanaka $\mathrm{K}$, Iorya $\mathrm{T}$, Kimura $\mathrm{T}$ (1997) A red-tide bloom of Chattonella antique (Raphidophyceae) in the Seto Inland Sea, Japan, in 1987 analysed as changes in photosynthetic pigments determined by

Editorial responsibility: Otto Kinne (Editor-in-Chief), Oldendorf/Luhe, Germany high-performance liquid chromatography. Water Res 31: $2269-2277$

Legrand C, Graneli E, Carlsson P (1998) Induced phagotrophy in the photosynthetic dinoflagellate Heterocapsa triquetra. Aquat Microb Ecol 15:65-75

Lindahl O (1995) Long-term studies of primary production in the Gullmar fjord, Sweden In: Skjoldal HR, Hopkins C, Erikstad KE, Leinaas HP (eds) Ecology of fjords and coastal waters. Elsevier Science Publishers, New York, p 105-112

Litaker RW, Tester PA, Duke CS, Kenney BE, Pinckney JL, Ramus J (2002) Seasonal niche strategy of the bloomforming dinoflagellate Heterocapsa triquetra. Mar Ecol Prog Ser 232:45-62

Montoya JP, Carpenter EJ, Capone DG (2002) Nitrogen fixation and nitrogen isotope abundances in zooplankton of the oligotrophic North Atlantic. Limnol Oceanogr 47: $1617-1628$

Nakamura Y, Yamazaki Y, Hiromi J (1992) Growth and grazing of a heterotrophic dinoflagellate, Gyrodinium dominans, feeding on a red tide flagellate, Chattonella antiqua. Mar Ecol Prog Ser 82:275-279

Naustvoll LJ (2000) Prey size spectra in naked heterotrophic dinoflagellates. Phycologia 39:448-455

Naustvoll LJ, Dahl E, Danielssen D (2002) A new bloom of Chattonella in Norwegian waters. Harmful Algae News 23:3-5

Ono C, Yoshimatsu S, Yoshida Y (1999) The relationship between the bloom of Chattonella antiqua (Hada) Ono and the water quality or meteorological factors. Nippon Suisan Gakkaishi 65:665-672

Parsons TR, Maita Y, Lalli CM (1984) A manual of chemical and biological methods for seawater analysis. Pergamon Press, New York

Tanaka K, Yoshimatsu S, Shimada M (1992) Generation of super oxide anions by Chattonella antiqua-possible causes for fish death caused by red tide. Experientia 48: 888-890

Tiffany MA, Barlow SB, Matey VE (2001) Chattonella marina (Raphidophyceae), a potentially toxic alga in the Salton Sea, California. Hydrobiologia 466:187-194

Utermöhl H (1958) Zur Vervollkommnung der quantitativen Phytoplankton Methodik. Mitt Int Ver Theor Angew Limnol 9:1-38

Voss M, Dippner JW, Montoya JP (2001) Nitrogen isotope patterns in the oxygen deficient waters of the Eastern Tropical North Pacific Ocean. Deep-Sea Res 48: 1905-1921

Vrieling EG, Koeman RPT, Nagasaki K, Ishida Y, Peperzak L, Gieskes WWC, Veenhuis M (1995) Chattonella and Fibrocapsa (Raphidophyceae): first observation of potentially harmful red tide organisms in Dutch coastal waters. Neth J Sea Res 33:183-191

Waite AM, Gustafsson O, Lindahl O, Tiselius P (2005) Linking ecosystem dynamics and biogeochemistry: sinking fractionation of organic carbon in a Swedish fjord. Limnol Oceanogr 50:658-671

Submitted: September 11, 2003; Accepted: February 9, 2006 Proofs received from author(s): October 10, 2006 